\title{
ATAXIA-TELANGIECTASIA MUTATED KINASE (ATM) AS A CENTRAL REGULATOR OF RADIATION-INDUCED DNA DAMAGE RESPONSE
}

\author{
Aleš Tichýl,3, Jiřina Vávrová ${ }^{1}$, Jaroslav Pejchal ${ }^{2}$, Martina Řezáčováa \\ University of Defence in Brno, Faculty of Military Health Sciences in Hradec Králové, Czech Republic: Department of \\ Radiobiology ${ }^{1}$, Centre of Advanced Studies²; Charles University in Praha, Faculty of Medicine and University Hospital \\ Hradec Králové, Czech Republic: Department of Medical Biochemistry ${ }^{3}$
}

Summary: Ataxia-telangiectasia mutated kinase (ATM) is a DNA damage-inducible protein kinase, which phosphorylates plethora of substrates participating in DNA damage response. ATM significance for the cell faith is undeniable, since it regulates DNA repair, cell-cycle progress, and apoptosis. Here we describe its main signalling targets and discuss its importance in DNA repair as well as novel findings linked to this key regulatory enzyme in the terms of ionizing radiationinduced DNA damage.

Key words: ATM; p53; Ionising radiation; DNA repair

\section{Introduction}

Exposure of mammalian cells to physical or chemical factors can result in DNA lesions as intermolecular crosslinking, single or double strand breaks and others (23). Double strand breaks (DSB) cause chromatin remodelling and formation of so-called ionising radiation-induced foci (IRIF), where during the first minutes after irradiation the proteins involved in DNA repair are localized. Among these are e.g. ataxia-telangiectasia mutated kinase (ATM), proteins of MRN complex (Mre11, Rad50, and Nbs1), Mdc1, p53-binding protein 1 (53BP1), and BRCA1 (6).

Activation of ATM is one of the first steps linked to DNA damage response after the exposure to ionising radiation (IR; 27). ATM is derived from ataxia-telangiectasia (A-T), human autosomal recessive disorder, which responsible gene is mutated. Already 30 years ago Taylor (54) proposed that extremely high number of radiation-induced chromosomal aberrations in A-T patient cells in comparison to the normal ones is caused due to un-repaired DSB, and that this is the reason of increased radio-sensitivity of A-T patient, which was observed in clinical practice. Kastan et al. (22) proved that A-T is a disease with defective cell-cycle checkpoint, where p53-dependent G1/S arrest does not occurre.

A-T cells exhibit specific genotype and besides increased radio-sensitivity these cells are characterized by genomic instability, cancer predispositions and increased sensitivity to radio-mimetics and inhibitors of topoisomerase I and II (27). ATM, a defective gene in this pleiotropic disease (pro- gressive cerebral ataxia, oculocutaneous telangiectasia, immunodeficiency), encodes serine/threonine kinase from a wide family of phosphatidylinositol-3 kinases. The importance of ATM is undeniable, because it regulates all three cell-cycle checkpoints. It also functions in DNA repair and apoptosis regulation and therefore it is a key regulator of cellular DNA damage response (23).

\section{ATM and p53}

In the last two decades a large number of ATM substrates, which are activated by phosphorylation, were identified. We will focus on those, which are required for cell-cycle arrest and DNA repair and participate on G1/S checkpoint. These are protein p53 (TP53), checkpoint kinase-2 (chk-2), and murine double minute protein-2 ( $\mathrm{mdm} 2)$. The last two are p53-dependent and ATM uses them to set appropriate activity and stability of p53 (22).

Tumour suppressor p53 is in a normal cell present in a latent form with low affinity to specific sequences of DNA but after genotoxic stress its activity increases substantially. Once activated, p53 acts as a key mediator of the cell faith, since it is capable of initiation of cell-cycle arrest, senescence or apoptosis via activation of $\mathrm{p} 53$-inducible genes $(26,58)$. A wide range of studies links its activation to the process of DNA reparation (47).

Human p53 is a polypeptide consisting of 393 amino acids $(53 \mathrm{kDa})$ and in a solution adopts conformation of tetramer (59). Gene for p53 is localized on a short shoulder of chromosome 17. This protein comprises several domains: 
transactivation (1-67), proline (67-98), central (98-303), nuclear localization signal-containing region (303-323), oligomerization (323-363) and C-terminal domain (363-393); the central domain is responsible for binding to specific DNA sequences in the vicinity of promoter region of $\mathrm{p} 53$ inducible genes (11).

Unlike the other transcriptional factors p53 contains also a second DNA binding (C-terminal) domain, by which it creates the stabile complexes with nonspecific sequences as single or double strand breaks or incorrectly paired DNA $(2,32)$. Phosphorylation on serine 392 localized in this domain enhances p53 binding to specific DNA sequences (12).

Because phosphorylation and dephosphorylation of p53 can critically influence the cell faith, very efficient regulatory mechanisms are needed. Regulation of p53 activity after exposure to IR (not UV-radiation) is to a great extent ATM-dependent and can be controlled in three ways: i) via subcellular localization; ii) by proteolytic degradation mediated by ubiquitin; iii) via allosteric modification on the main DNA binding domain (12).

Since p53 acts in the nucleus, the change of subcellular localization is a logical way of regulation of its activity. Nevertheless, transfer to cytoplasm requires previous binding to ubiquitin (targeting) mediated by oncoprotein $\mathrm{mdm} 2$, which is an E3 ubiquitin ligase $(7,20)$. Mdm2 is essential for effective p53 degradation (46) and it was proved to be phosphorylated on serine 166 and 395 in ATM-dependent manner in vitro $(24,38)$. The recent model perceives p53 and $\mathrm{mdm} 2$ in a tight auto-regulatory bond. Protein $\mathrm{p} 53$ induces $\mathrm{mdm} 2$ transcription, which directly binds to $\mathrm{p} 53$ $\mathrm{N}$-terminus thus blocking its further transcriptional activity and maintaining its degradation (39).

If the cell is exposed to the DSB-inducing stress such as IR, this tight bond is interrupted and p53 is phosphorylated in order to block the effect of mdm2. P53-mdm 2 model is controlled by ATM directly via p53 phosphorylation on serine 15 and indirectly via phosphorylation on serine 20 that is conducted by chk-2, a kinase activated by ATM on threonine $68(3,8,19$, and 36). These phosphorylations make p53 more resistant to the inhibitory effects of mdm 2 and moreover they stimulate its transcriptional activity.

\section{p53 and p21}

Transcriptional activity of p53 is also supported by 53BP1. It contains $\mathrm{C}$-terminal domains for $\mathrm{p} 53$ binding and one domain responsible for binding of phosphorylated histone $\mathrm{H} 2 \mathrm{AX}$, which is necessary for retention of 53BP1 in the localization of DSB (41). Its significance derives especially from its participation in IRIF formation important for DSB repair and tumour suppression $(48,60)$.

The main transcription target of $\mathrm{p} 53$, which regulates G1/S arrest, is protein p21 (WAF1/Cip/Sdi1), which together with p 27 and p57 creates family of proteins sharing the ability to inhibit a wide range of cyklin-dependent kinases (cdk) and thus they can induce the cell cycle arrest (49).
G1/S checkpoint is controlled by interaction of E2F protein (a member of essential transcription factors family) with $\mathrm{pRb}$ (retinoblastoma susceptibility protein). E2F is associated with DNA in the promoter region; unphosphorylated $\mathrm{pRb}$ is tightly bound to E2F and attracts histone deacetylases (enzymes cleaving acetyl groups from $\mathrm{N}$-termini of histones). Histone deacetylation induces histone comprimation and transcription of certain genes is blocked due to the tight conformation and limited access of required molecules. Therefore the presence of unphosphorylated $\mathrm{pRb}$ leads to the repression of specific genes required to the progression of the cell cycle and the checkpoint is closed. When p21 is not upregulated it does not inhibit cdk4 and cdk6 and they can react with D-type cyclin and induce phosphorylation of $\mathrm{pRb}$. This, in turn, leads to dissociation of $\mathrm{pRb}$ from the complex with E2F and the cell cycle can progress (rewieved in 42).

Taken together, p21 can induce cell cycle arrest. Moreover, it possesses other anti-proliferative functions as maintenance of differentiation and senescence (10) and it is also capable of modulation of apoptosis by interaction with caspase-3 $(51,52)$.

\section{ATM and cell cycle regulation}

Besides G1 checkpoint ATM regulates also the S-phase checkpoint, which underlines phenotype of so-called radioresistant DNA synthesis. This phenomenon was identified for the first time in the A-T patients as the inability to suppress replication of DNA within IR-induced damage response (33). In this checkpoint chk-2 (activated by ATM) phosphorylates phosphatase $\mathrm{Cdc} 25 \mathrm{~A}$, which results in the binding of the latter to 14-3-3 protein and its subsequent degradation (14). Degraded Cdc25A then can non dephosphorylate cdk2, which is required for DNA synthesis. Falck et al. (14) showed that mutations in ATM/chk-2/Cdc25A/ cdk2 pathway lead to inability of the cells to inhibit the DNA synthesis. The same group also proved that a parallel mechanisms, by which ATM controls S-checkpoint, exists demanding MRN complex (15).

The last cell cycle checkpoint regulated by ATM is G2/M checkpoint, necessary for the cell cycle arrest of the cells, which were irradiated in the G2-phase. Processes in this checkpoint are chk-1/chk-2-dependent, since their active forms can inhibit activation of $\mathrm{Cdc} 25 \mathrm{C}$ phosphatase. Active $\mathrm{Cdc} 25 \mathrm{C}$ is required for cyclin $\mathrm{B} 1$ and cdk 1 activation and for progression of the cell cycle (34).

Thus, ATM regulates a wide range of target molecules by phosphorylation. Beside those mentioned above also Nbs1, Brca1, FancD2, and SMC1 take part in S-phase cell cycle arrest $(53,62$, and 63$)$ and Brcal and Rad17 are partially involved in $\mathrm{G} 2 / \mathrm{M}$ checkpoint $(4,61)$.

\section{ATM and DNA repair}

During ATM activation after irradiation the key factor is a rapid intramolecular phosphorylation at serine 1981, 
which induces dissociation of an inactive dimer and triggers ATM activity (1). Also a specific protein complex is required for its activation - MRN complex consisting of Mre11, Rad50, and Nbs1 protein (56). It was proved that ATM is not activated without MRN complex and that mutation of its components leads to genetic disorder as neurological abnormalities, radio-sensitivity, cell cycle defects, genomic instability, and cancer predispositions (28). MRN complex is associated with chromatin during DNA replication and it can recognize DSB and transmit this information to ATM by attraction of ATM to the damaged DNA (30).

Importantly, MRN complex is able to bind DNA without involvement of active ATM suggesting that MRN complex is the entire sensor of DSB $(29,40)$. Anyway, once activated ATM is the central DSB signalling transducer.

An outbreaking finding is that Nbs1 is dispensable for ATM activation, but its C-terminal motif is required for localization of ATM in the site of damage (16). Very rear autosomal recessive disorder "Nijmegen Breakage Syndrome" is characterized by microcephalia, immunodeficiency, and predispositions to haematological malignancies and this syndrome is caused by mutation of $N b s 1$ gene (13). Another protein of MRN complex, Rad50, functions as a protective chromosomal factor. It impedes excessively rapid shortening of telomeres and so-called end-to-end joining of sister chromatids (57).

The particular proteins of MRN complex regulate each others. For instance, Nbs 1 recruits Mre11 into the nucleus and Mre 11 increases Nbs1 stability (33). Ghosal et al. (17) in their study performed on yeast reported that Mre11 exhibits specific endonuclease activity towards DNA with DSB and Rad50 inhibits this activity. Therefore they proposed that creation of Mre11-Rad50 complex is important for blocking of unwanted DNA cleavage and maintaining the length of the telomeres.

Radio-sensitivity of the A-T cells derives from their decreased ability to repair the damaged DNA (54). There are two main mechanisms of DSB repair; non-homologous endjoining (NHEJ) and homologous recombination (HR), whereas the first one is dominant in the mammalian cells (reviewed in 21). Unlike HR, which is driven by homologous sequence of DNA, during NHEJ is the presence of homologous template required minimally (18).

NHEJ is the mechanism, which is used mainly for reparation in G1- and early S-phase, but it is active during the whole cell cycle (35). Its disadvantage is that it can lead to a large number of irrelevant joints in the case that the given apparatus does not recognize, which parts of DNA should be jointed. The core of the system is heterodimer complex of DNA-dependent protein kinases $\mathrm{Ku} 70 / \mathrm{Ku} 80$, which ensures initiation of NHEJ. X-ray cross complementing protein (XRCC4) is helping protein, which was discovered in highly radio-sensitive cell lines with defective DSB reparation, and it binds to another important part of the system DNA ligase IV - to form the complex important for neuro- genesis (55). In mice lacking XRCC4 or DNA ligase IV gene massive apoptosis occurs in neural cells and mutations in human fibroblast cell line 180BR (derived from patient with lymphatic leukaemia) leading to higher radiosensitivity, were according to Riballo et al. (44) linked to DNA ligase IV and the inability to repair the radiation damage by NHEJ.

The HR system uses homologue DNA sequence as an undamaged matrix (template), thus enabling correct repair and end-joining of DNA. HR is very accurate repair mechanism and it is processed from late S-phase to G2-phase. In this period, the sister chromatides, which serve as a template to guide DSB repair, are available (43). MRN complex is crucial for this process as well as ATM. ATM regulates this process by phosphorylation and association with breast cancer susceptibility gene product (BRCA1). BRCA1 protein is also phosphorylated by ATM indirectly (via chk-2) in order to bind to Rad51 (31). This catalyzes ATP-dependent pairing and exchange of DNA strands between homologue sequences. Moreover, Rad51 activity is modulated by Abelson murine leukemia viral oncogene homolog 1 (c-Abl) phosphorylation and c-Abl is a downstream substrate of ATM (64). Besides that ATM participates in HR through modulation of chromatin structure and alteration of phosphorylation and acetylation of histones.

ATM after irradiation associates with chromatin and also with histonedeacetylases, thus facilitating access of HR proteins to the sites of damaged DNA (23). The very early step in the DNA damage response is phosphorylation of histone subtype H2A, class H2A.X. This process can be executed by two independent protein kinases - DNA-dependent protein kinase and ATM - and therefore it might be observed even in A-T cell lines (50). H2A.X phosphorylated on serine $139(\gamma \mathrm{H} 2 \mathrm{~A} . \mathrm{X})$ can be visualized by a suitable antibody via immunofluorescence as a discrete spot (focus) and it has been reported that it is localized in the area up to $2 \times 10^{6}$ basis from the site of DSB (45). Although $\gamma \mathrm{H} 2 \mathrm{~A} . \mathrm{X}$ is not essential for NHEJ and HR, it seems to be an important modulator of both (5). Kim et al. (25) liken it to a protein docking site. It is probably needed for retention of some proteins participating on DNA repair rather than for their binding and it is important for assembly of reparation complex in the site of DSB (9).

\section{Conclusion}

It is no doubt that ATM is of a paramount importance in the regulation of DNA repair. A robust signalling network has been developed in order to be activated within seconds after the DNA damage and NHEJ and HR pathways are then responsible for its reparation. Nowadays, the proteomic approach revealed more than 700 proteins involved in the complex DNA repair machinery (37) hence the complexity of the system is more than obvious. We already managed to answer some of the questions about the sensors and transducers, which mediate the DNA damage response. 
However, we still search for the exact mechanism of ATM activation, although we know that MRN is an indispensable foundation. We still do not properly understand what is the trigger of ATM auto-phosphorylation? What does influence the NHEJ or HR decision making? How do ATM and other kinases regulate their co-operation? What is the role of the recently discovered proteins in DNA damage signalling? It is likely that addressing these and other questions will accelerate development of therapeutic tools and deeper comprehension of DNA damage response will also establish new platforms for treatment strategies in oncology.

\section{Acknowledgement}

This work was supported by Ministry of Defence, Czech Republic (project MO0FVZ0000501 and project OVUOFVZ200806).

\section{List of abbreviations}

$\begin{array}{ll}\text { A-T } & \text { ataxia-telangiectasia } \\ \text { ATM } & \text { ataxia-telangiectasia mutated kinase } \\ \text { cdk } & \text { cyclin-dependent kinase } \\ \text { chk-2 } & \text { checkpoint kinase-2 } \\ \text { DSB } & \text { double strand break } \\ \text { E2F } & \text { protein of essential transcription factors family } \\ \gamma H 2 A . X & \text { histone H2A.X phosphorylated on serine 139 } \\ \text { HR } & \text { homologous recombination } \\ \text { IR } & \text { ionising radiation } \\ \text { mdm2 } & \text { murine double minute protein-2 } \\ \text { MRN } & \text { Mre11/Rad50/Nbs1 complex } \\ \text { NHEJ } & \text { non-homologous end-joining } \\ \text { pRb } & \text { retinoblastoma susceptibility protein }\end{array}$

\section{References}

1. Bakkenist C, Kastan MB. DNA damage activates ATM through intermolecular autophosphorylation and dimmer dissociation. Nature 2003;421:499-506.

2. Bakalkin G, Yakovleva T, Selivanova G, Magnusson KP, Szekely L, Kiseleva E, Klein G, Terenius L, Wiman KG. p53 binds single-stranded DNA ends through the C-terminal domain and internal DNA segments via the middle domain. Nucleic Acids Res 1995;23:362-9.

3. Banin S, Moyal L, Shieh S, Taya Y, Anderson CW, Chessa L, Smorodinsky NI, Prives C, Reiss Y, Shiloh Y, Ziv Y. Enhanced phosphorylation of p53 by ATM in response to DNA damage. Science 1998;281:1674-7.

4. Bao S, Tibbetts RS, Brumbaugh KM, Fang Y, Richardson DA, Ali A, Chen SM, Abraham RT, Wang XF. ATR/ATM-mediated phosphorylation of human Rad17 is required for genotoxic stress responses. Nature 2001:411:969-74.

5. Bassing CH, Chua KF, Sekiguchi J, Suh H, Whitlow SR, Fleming JC, Monroe BC, Ciccone DN, Yan C, Vlasakova K, Livingston DM, Ferguson DO, Scully R, Alt FW. Increased ionizing radiation sensitivity and genomic instability in the absence of histone H2AX. Proc Natl Acad Sci 2002;99:8173-8.

6. Bekker-Jensen S, Lukas C, Kitagawa R, Melander F, Kastan MB, Bartek J, Lukas J. Spatial organization of the mammalian genome surveillance machinery in response to DNA strand breaks. J Cell Biol 2006;173:195-206.

7. Boyd SD, Tsai KY, Jacks T. An intact HDM2 RING-finger domain is required for nuclear exclusion of p53. Nat Cell Biol 2000;2:563-8.

8. Canman CE, Lim DS, Cimprich KA, Taya Y, Tamai K, Sakaguchi K, Appella E, Kastan MB, Siliciano JD. Activation of the ATM kinase by ionizing radiation and phosphorylation of $\mathrm{p} 53$. Science 1998;281:1677-9.

9. Celeste A, Petersen S, Romanienko PJ, Fernandez-Capetillo O, Chen HT, Sedelnikova OA, Reina-San-Martin B, Coppola V, Meffre E, Difilippantonio MJ, Redon C, Pilch DR, Olaru A, Eckhaus M, Camerini-Otero RD, Tessarollo L, Livak F, Manova K, Bonner WM, Nussenzweig MC, Nussenzweig A. Genomic instability in mice lacking histone H2AX. Science 2002;296:922-7.
10. Child ES, Mann DJ. The intricacies of p21 phosphorylation: protein/protein in teractions, subcellular localization and stability. Cell Cycle 2006;5:1313-9.

11. Cho Y, Gorina S, Jeffrey PD, Pavletich NP. Crystal structure of a p53 tumo suppressor-DNA complex: understanding tumorigenic mutations. Science 1994;265:346-55

12. Criswell T, Leskov K, Miyamoto S, Luo G, Boothman DA. Transcription factors activated in mammalian cells after clinically relevant doses of ionizing radiation. Oncogene 2003;22:5813-27.

13. Digweed M, Sperling K. Nijmegen breakage syndrome: clinical manifestation of defective response to DNA double-strand breaks. DNA Repair (Amst) 2004; 3:1207-17

14. Falck J, Mailand N, Syljuasen RG, Bartek J, Lukas J. The ATM-Chk2 Cdc25A checkpoint pathway guards against radioresistant DNA synthesis. Nature 2001;410:842-7.

15. Falck J, Petrini JH, Williams BR, Lukas J, Bartek J. The DNA damage-dependent intra-S phase checkpoint is regulated by parallel pathways. Nat Genet 2002;30:290-4

16. Falck J, Coates J, Jackson SP. Conserved modes of recruitment of ATM, ATR and DNA-PKcs to sites of DNA damage. Nature 2005;434:605-11.

17. Ghosal G, Muniyappa K. The Characterization of Saccharomyces cerevisiae Mre11/Rad50/Xrs2 Complex Reveals that Rad50 Negatively Regulates Mre11 Endonucleolytic but not the Exonucleolytic Activity. J Mol Biol 2007;372: 864-82.

18. Haber JE. Partners and pathways repairing a double-strand break. Trends Genet 2000;16:259-64

19. Hirao A, Kong YY, Matsuoka S, Wakeham A, Ruland J, Yoshida H, Liu D, Elledge SJ, Mak TW. DNA damage-induced activation of $\mathrm{p} 53$ by the checkpoint kinase Chk2. Science. 2000;287:1824-7.

20. Honda R, Tanaka H, Yasuda H. Oncoprotein MDM2 is a ubiquitin ligase E3 for tumor suppressor p53. FEBS Lett 1997;420:25-7.

21. Jeggo PA. Identification of genes involved in repair of DNA double-strand breaks in mammalian cells. Radiat Res. 1998;150:80-91. Review.

22. Kastan MB, Onyekwere O, Sidransky D, Vogelstein B, Craig RW. Participation of p53 protein in the cellular response to DNA damage. Cancer Res 1991;51: 6304-11.

23. Khanna KK, Lavin MF, Jackson SP, Mulhern TD. Related Articles, Links ATM a central controller of cellular responses to DNA damage. Cell Death Differ 2001;8:1052-65. Review.

24. Khosravi R, Maya R, Gottlieb T, Oren M, Shiloh Y, Shkedy D. Rapid ATM-dependent phosphorylation of MDM2 precedes $\mathrm{p} 53$ accumulation in response to DNA damage. Proc Natl Acad Sci USA 1999;96:14973-7.

25. Kim JE, Minter-Dykhouse K, Chen J. Signaling networks controlled by the MRN complex and MDC1 during early DNA damage responses. Mol Carcinog 2006; 45:403-8

26. Ko LJ, Prives C. p53: puzzle and paradigm. Genes Dev 1996;10:1054-72.

27. Lavin MF, Shiloh Y. The genetic defect in ataxia-telangiectasia. Annu Rev Immunol 1997;15:177-202.

28. Lavin MF. The Mre11 complex and ATM: a two-way functional interaction in recognising and signaling DNA double strand breaks. DNA Repair (Amst) 2004 3:1515-20.

29. Lavin MF. ATM and the Mre11 complex cosine to recognize and signal DNA double-strand breaks. Oncogene 2007;26:7749-58.

30. Lee JH, Paull TT. ATM activation by DNA double-strand breaks through the Mre11-Rad50-Nbs 1 complex. Science 2005;308:551-4.

31. Lee JS, Collins KM, Brown AL, Lee CH, Chung JH. hCds1-mediated phosphorylation of BRCA1 regulates the DNA damage response. Nature 2000:404:201-4

32. Lee S, Elenbaas B, Levine A, Griffith J. p53 and its $14 \mathrm{kDa}$ C-terminal domain recognize primary DNA damage in the form of insertion/deletion mismatches. Cell 1995:81:1013-20.

33. Löbrich M, Jeggo PA. The two edges of the ATM sword: co-operation between repair and checkpoint functions. Radiother Oncol 2005;76:112-8. Review.

34. Lukas J, Lukas C, Bartek J. Mammalian cell cycle checkpoints: signalling pathways and their organization in space and time. DNA Repair (Amst) 2004;3: 997-1007. Review.

35. Ma Y, Lu H, Schwarz K, Lieber MR. Repair of double-strand DNA breaks by the human nonhomologous DNA end joining pathway: the iterative processing model. Cell Cycle 2005;4:1193-200.

36. Matsuoka S, Rotman G, Ogawa A, Shiloh Y, Tamai K, Elledge SJ. Ataxia telangiectasia-mutated phosphorylates Chk2 in vivo and in vitro. Proc Natl Acad Sci USA 2000;97:10389-94.

37. Matsuoka S, Ballif BA, Smogorzewska A, McDonald ER $3^{\text {rd }}$, Hurov KE, Luo J, Bakalarski CE, Zhao Z, Solimini N, Lerenthal Y, Shiloh Y, Gygi SP, Elledge SJ. ATM and ATR substrate analysis reveals extensive protein networks responsive to DNA damage. Science 2007;316:1160-6.

38. Maya R, Balass M, Kim ST, Shkedy D, Leal JF, Shifman O, Moas M, Buschmann T, Ronai Z, Shiloh Y, Kastan MB, Katzir E, Oren M. ATM-dependent phosphorylation of Mdm2 on serine 395: Role in p53 activation by DNA damage. Genes Dev 2001;15:1067-77. 
39. Michael D, Oren M. The p53-Mdm2 module and the ubiquitin system. Semin Cancer Biol 2003;13:49-58. Review.

40. Mirzoeva OK, Petrini JH. DNA replication-dependent nuclear dynamics of the Mre11 complex. Mol Cancer Res 2003;1:207-18.

41. Mochan TA, Venere M, DiTullio RA Jr, Halazonetis TD. 53BP1, an activator of ATM in response to DNA damage. DNA Repair (Amst) 2004;3:945-52.

42. Pollard TD, Earnshaw WC. Cell biology. 1. vyd. Philadelphia: Sander, Elsevier Science, 2002:688-9.

43. Reliene R, Bishop AJ, Schiestl RH. Involvement of homologous recombination in carcinogenesis. Adv Genet 2007;58:67-87.

44. Riballo E, Critchlow SE, Teo SH, Doherty AJ, Priestley A, Broughton B, Kysela B, Beamish H, Plowman N, Arlett CF, Lehmann AR, Jackson SP, Jeggo PA Identification of a defect in DNA ligase IV in a radiosensitive leukaemia patient. Curr Biol 1999;9:699-702.

45. Rogakou EP, Boon C, Redon C, Bonner WM. Megabase chromatin domains involved in DNA double-strand breaks in vivo. J Cell Biol 1999;146:905-16.

46. Roth J, Dobbelstein M, Freedman DA, Shenk T, Levine AJ. Nucleo-cytoplazmic shuttling of the hdm 2 oncoprotein regulates the levels of the p53 protein via a pathway used by the human immunodeficiency virus rev protein. EMBO J 1998; 17:554-64.

47. Sengupta S, Harris CC. p53: traffic cop at the crossroads of DNA repair and recombination. Nat Rev Mol Cell Biol 2005;6:44-55.

48. Schultz LB, Chehab NH, Malikzay A, Halazonetis TD. p53 binding protein 1 (53BP1) is an early participant in the cellular response to DNA double-strand breaks. J Cell Biol 2000;151:1381-90.

49. Schwartz GK. CDK inhibitors: cell cycle arrest versus apoptosis. Cell Cycle 2002;1:122-3. Review.

50. Stiff T, O’Driscoll M, Rief N, Iwabuchi K, Lobrich M, Jeggo PA. ATM and DNAPK function redundantly to phosphorylate $\mathrm{H} 2 \mathrm{AX}$ after exposure to ionizing radiation.Cancer Res 2004;64:2390-6.

51. Suzuki A, Tsutomi Y, Akahane K, Araki T, Miura M. Resistance to Fas-mediated apoptosis: activation of caspase 3 is regulated by cell cycle regulator p21WAF1 and IAP gene family ILP. Oncogene 1998;17:931-9.

52. Suzuki A, Tsutomi Y, Miura M, Akahane K. Caspase 3 inactivation to suppress
Fas-mediated apoptosis: identification of binding domain with p21 and ILP and inactivation machinery by $\mathrm{p} 21$. Oncogene $1999 ; 18: 1239-44$.

53. Taniguchi T, Garcia-Higuera I, Xu B, Andreassen PR, Gregory RC, Kim ST, Lane WS, Kastan MB, D'Andrea AD. Convergence of the Fanconi anemia and ataxia telangiectasia signaling pathways. Cell 2002;109:459-72.

54. Taylor AM. Unrepaired DNA strand breaks in irradiated ataxia telangiectasia lymphocytes suggested from cytogenetic observations. Mutat Res. 1978;50: 407-18.

55. Thacker J, Zdzienicka MZ. The mammalian XRCC genes: their roles in DNA repair and genetic stability. DNA Repair 2003;2:655-72.

56. Uziel T, Lerenthal Y, Moyal L, Andegeko Y, Mittelman L, Shiloh Y. Requirement of the MRN complex for ATM activation by DNA damage. EMBO J 2003;22:5612-21.

57. Vannier JB, Depeiges A, White C, Gallego ME. Two roles for Rad50 in telomere maintenance. EMBO J 2006;25:4577-85.

58. Vogelstein B, Lane D, Levine AJ. Surfing the p53 network. Nature 2000;408: $307-10$

59. Wang P, Reed M, Wang Y, Mayr G, Stenger JE, Anderson ME, Schwedes JF, Tegtmeyer P. p53 domains: structure, oligomerization, and transformation. Mol Cell Biol 1994;14:5182-91.

60. Ward IM, Minn K, van Deursen J, Chen J. p53 Binding protein 53BP1 required for DNA damage responses and tumor suppression in mice. Mol Cell Biol 2003; 23:2556-63.

61. Xu B, Kim ST and Kastan MB. Involvement of Brca1 in S-phase and G2-phase checkpoints after ionizing irradiation. Mol Cell Biol 2001;21:3445-50.

62. Xu B, O’Donnell AM, Kim ST and Kastan MB. Phosphorylation of serine 1387 in Brcal is specifically required for the Atm-mediated S-phase checkpoint after ionizing irradiation. Cancer Res 2002;62:4588-91.

63. Yazdi PT, Wang Y, Zhao S, Patel N, Lee EY, Qin J. SMC1 is a downstream effector in the ATM/NBS1 branch of the human S-phase checkpoint. Genes Dev 2002;16:571-82.

64. Yuan ZM, Huang Y, Ishiko T, Nakada S, Utsugisawa T, Kharbanda S, Wang R, Sung P, Shinohara A, Weichselbaum R, Kufe D. Regulation of Rad51 function by c-Abl in response to DNA damage. J Biol Chem 1998;273:3799-802.

Received: $10 / 02 / 2010$.

Accepted in revised form: 08/03/2010.

\section{Corresponding author:}

Aleš Tichý, MS, Ph.D., Faculty of Military Health Sciences, University of Defence, Třebešská 1575, 50001 Hradec Králové, Czech Republic; e-mail: tichy@pmfhk.cz 